
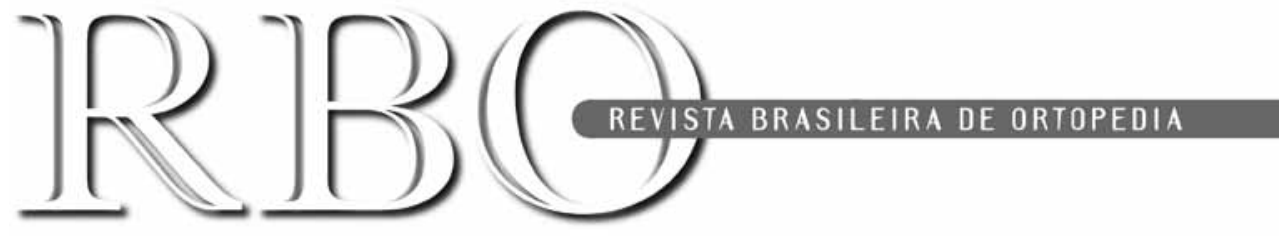

\title{
Editorial
}

\section{Trauma Ortopédico Multitasking}

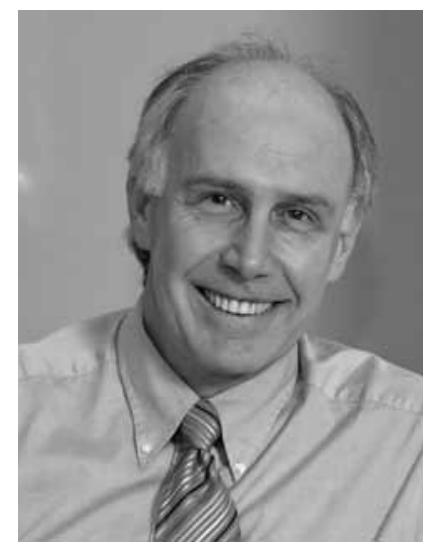

O Comitê de Trauma Ortopédico da SBOT entrega uma obra marcante - um conjunto de artigos científicos de excelente qualidade. O objetivo é mais do que meritório, pois possibilita que este material, que teve apresentação oral no XV1l Congresso Brasileiro de Trauma Ortopédico, em maio de 2011 em Salvador, Bahia, tenha também apresentação escrita, possibilitando aos autores a incorporação nos seus currículos.

O Comitê de Trauma Ortopédico faz muito mais em prol da ortopedia brasileira e internacional - educa, atualiza, publica, faz pesquisa de opinião, possui interface governamental, relaciona-se com entidades internacionais de fomento científico, aprimora seu quadro de associados, dentre outros. Por isso, pode ser identificada como sociedade multitasking, ou seja, realiza várias atividades de forma simultânea. E com a mesma competência!

O trauma ortopédico é assunto muito atual. A ONU, em conjunto com a OMS, lança em 11 de maio de 2011 a Década Mundial de Ações para uma Trânsito Seguro. A data coincide com a distribuição deste suplemento, além de outras ações já tomadas pela SBOT. Trata-se, portanto, do imediato engajamento dos ortopedistas brasileiros a este esforço global, que foi tomado depois que estudos concluíram que o acidente de trânsito vitimará mais pessoas do que o câncer e as doenças cardio-vasculares em menos de 10 anos, se tornando na causa mortis número um do mundo, se medidas globais não forem tomadas agora. O número de vítimas fatais a cada ano assusta a todos - são cerca de 40.000 no Brasil e 1.300.000 no mundo. Quadro ainda pior é a relação de 01 morte / 11 indivíduos com sequela permanente / 38 internações hospitalares / 380 atendimentos em emergências. O custo Brasil é de R $\$ 30$ bilhões de reais anuais. Uma liderança mundial com péssima reputação.

Sabemos que para cada grande trauma existem muitos outros médios e pequenos, todos necessitando de uma equipe multidisciplinar, onde o ortopedista tem posição de liderança. Estamos, pois, na linha de frente no atendimento do paciente traumatizado.

Este suplemento traz indispensável atualização sobre o tema, com novos enfoques produzidos por talentosos membros da Sociedade Brasileira de Trauma Ortopédico (SBTO).

Cumprimento ao amigo Maurício Kfuri Jr. e toda a sua diretoria, bem como as que antecederam, pelo esforço e dedicação no exercício da liderança institucional. A preservação da vida e a restauração das funções músculo-esqueléticas continua sendo a nossa maior missão.

Boa leitura!

Osvandré Lech

Presidente da SBOT

\section{GESTÃO 2011}

Geraldo da Rocha Motta Filho; Flávio Faloppa; Jorge dos Santos Silva;

Marcelo Tomanik Mercadante; Ney C. Pecegueiro do Amaral; Adalberto Visco; Reynaldo Jesus Garcia Filho

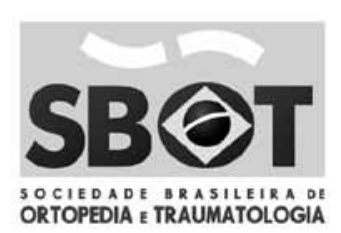

